\title{
THE RELATIONSHIP BETWEEN READING INTEREST WITH LEARNING OUTCOMES ELEMENTARY SCHOOL STUDENTS
}

\author{
Azizah $^{a}$, Uswatun Hasanah ${ }^{b}$ \\ Department of Education, Faculty of Teacher Training and Education, Tadulako University \\ Corresponding Author: azizahrosnadi@gmail.com
}

\begin{abstract}
This study aims to determine the relationship between reading interest and students' Indonesian learning outcomes. This type of research uses quantitative methods with a correlation research design. What conducted this research in the fourth grade of SD Inpres 1 Donggulu. The instruments used in this research are questionnaires and documentation. The data analysis technique used is descriptive statistics, normality test, product-moment correlation, and coefficient of determination $(K D)$. The results showed that reading interest was strong, and Indonesian language learning outcomes were excellent. The results of the calculation of the product-moment correlation show that count > r-table $(0.511>0.468)$, then $\mathrm{Ha}$ is accepted and $\mathrm{HO}$ is rejected, meaning that there is a significant relationship between reading interest and Indonesian language learning outcomes for fourth-grade students of SD Inpres 1 Donggulu. The relationship between reading interest and Indonesian language learning outcomes for fourth-grade students of SD Inpres 1 Donggulu has a moderate association level. If present, it is $26 \%$, while other factors influence the remaining $74 \%$.
\end{abstract}

\section{Keywords: Reading Interest; Indonesian Language Learning Outcomes}

\section{INTRODUCTION}

Education is a social activity that allows society to exist and develop (Reskia et al., 2014). In essence, education lasts a lifetime and is a shared responsibility between families, communities, and governments. The function and role of education, both individually and collectively, is an essential factor in building a whole person and preparing quality human resources. (Andriani et al., 2014). Therefore, the Indonesian government has launched a nine-year compulsory basic education program to equalize educational opportunities for all Indonesian citizens. Based on Government Regulation of the Republic of Indonesia number 47 of 2008 concerning mandatory education, it is explained that compulsory education is a minimum education program that must be followed by Indonesian citizens on the responsibility of the government and local governments. The minimum education in question is from elementary school and equivalent to junior high school and equivalent or for nine years.

Elfika et al. (2014) argue that "schools as educational institutions must be able to utilize all educational resources as much as possible, improve learning abilities, both the learning abilities of students, teachers, managers and the ability to learn the school itself as an organism, if the school already has these abilities, then the quality school education has improved." Elementary School is part of the nine-year compulsory education program and was the first educational institution to emphasize learning to read, write, and count. These skills are the foundation and requirements for students to acquire knowledge. Without mastery of skills, students will have difficulty mastering science. In addition to learning these skills, the essential thing to master science is to master the language.

According to BSNP (2006), language has a central role in students' intellectual, social, and emotional development and supports success in learning all fields of study. Language learning is expected to help students get to know themselves, their culture, and the cultures of others, express ideas, and feelings, participate in communities that use the language, and discover and use their analytical and imaginative abilities. Therefore, in elementary schools throughout Indonesia, Indonesian language learning is carried out. The scope of Indonesian language subjects in elementary schools covers four aspects of language skills, namely listening or listening, speaking, reading, and writing. 
In Permendiknas number 23 of 2006 concerning Graduate Competency Standards, it is stated that the Graduate Competency Standards for Elementary Schools/Madrasah Itidaiyah, Extraordinary Elementary Schools/Package A include, among others, showing a passion for reading and writing, and demonstrating listening, speaking, reading, writing and count. Thus, reading activities are essential to be instilled in children early to help the learning process. In the world of education, reading is a necessary factor in the learning process at school. Reading is also one of the main doors to access knowledge and information. Hodgson in Tarigan (2008) argues that "reading is a process carried out and used by readers to get the message to be conveyed by the author through the medium of words or written language." So by reading, students can gain knowledge provided by the author. The more a student reads, the wider his expertise and insight will be. Affect the learning process and the mindset of the students concerned.

A person's reading habits are determined by various factors, one of which is interest. Interest is the tendency to pay attention and enjoy some activities. Interest is an internal factor that influences someone to do something, one of which is reading. People who have an interest in reading activities will tend to like and pay attention to these activities. On the other hand, if people have less interest in reading, then that person will not do these activities with a sense of love. Lilawati in Sudarsono (2010) stated that "interest in reading is a strong and deep concern accompanied by feelings of pleasure towards reading activities so that it directs individuals to read on their own accord." Interest in reading is one of the essential keys for someone to acquire knowledge and information.

The rapid development of technology has made elementary school students, especially in urban areas and from well-to-do families, have free internet access through their cell phones. In addition, there are online games and PS (Play Station), which are popular with elementary school students. In Indonesia, television shows are increasingly presenting various spectacles, both decent and not suitable for elementary school-age students, becoming a distraction for students from reading books. The lack of reading culture in the environment can also affect students' interest in reading. Some students prefer to play cell phones and games, watch television, and play with their friends than reading books. In addition, some students only read books if there is an assignment or test from the teacher.

Researchers conducted observations at the Donggulu Inpres 1 Elementary School, Kasimbar District, Parigi Moutong Regency. The school's library is well-organized, and the collections are varied. The number of book collections is about hundreds of more books. Library facilities also look excellent and adequate. Students visit the library, the teacher gives assignments to borrow books and read them. Some students visit the library during recess, and some prefer to play in the schoolyard or sit on the baruga in front of their class.

One of SD Inpres 1 Dongulu in high grades is the lack of interest in reading. Students only read when asked to and only when there was an order to read in their assignment book. There are even some students who still feel embarrassed to read in front of the class. The library, which is a place to read books, looks deserted because students rarely visit it.

Based on the description above, a study was conducted to determine the relationship between reading interest and Indonesian language learning outcomes for fourth-grade students of SD Inpres 1 Dongguan. With this research, it is hoped that in the future, teachers can foster student interest in reading by doing various ways and methods so that reading culture does not become extinct. The importance of reading is that we can see the world without traveling. The researcher will conduct a study entitled "The relationship between reading interest and learning outcomes of Indonesian language students in fourth grade SD Inpres 1 Donggulu" from the background description.

Based on the formulation of the problem described, the purpose of this study is to find out the relationship between reading interest and Indonesian language learning outcomes for fourth-grade students of SD Inpres 1 Donggulu. 


\section{LITERATURE REVIEW}

Reading interest is an activity carried out with full diligence to build a pattern of communication with oneself to find the meaning of writing and find information to develop intellectually, which is carried out with full awareness and feelings of pleasure that arise from within him. Interest in reading is also defined as a form of directed behavior to carry out reading activities as a strong level of satisfaction. Here interest in reading can be interpreted as a strong desire of a person to read. Therefore, the higher a person's interest in reading, the stronger his desire to read. (Dalman, 2014).

According to Bastiano and Sudarsono (2010), four aspects are used to determine a person's level of interest in reading, namely: a) the pleasure of reading; b) Awareness of the benefits of reading; c) Frequency of reading; and d) Quantity of Readings.

Learning outcomes are the achievement of educational goals for students who follow the learning process. Learning outcomes are often used as a measure to find out how far someone has mastered the material that has been taught. Abdurrahman explained in general that learning outcomes are the abilities that children get after going through learning activities. According to him, children who are successful in learning achieve learning goals or instructional goals in the Basic Education Profession journal, quoted from Azizah (2020).

Factors that affect learning outcomes, according to Slameto (2013) including internal factors and external factors. Internal factors include (a) physiological factors such as excellent health, not in a state of tiredness and fatigue, not in a state of physical disability, and so on. affect students in receiving the subject matter. (b) Psychological factors such as intelligence (IQ), attention, interests, talents, motives, motivation, cognitive and reasoning power of students. External factors include (a) instrumental factors such as curriculum, facilities, and teachers. (b) External factors such as the state of the family environment, the school environment, and the state of the community environment.

One of the skills expected to be possessed by elementary school students is good language skills because language is one of the essential capitals for humans in developing knowledge. Learning Indonesian in elementary school cannot be separated from four language skills: listening, speaking, reading, and writing. Each of these skills is closely related to the other three skills in various ways. In acquiring language skills, usually through a regular sequence relationship: first, in childhood, learn to listen to the language, then speak; Then, we know to read and write. Listening and speaking are learned before entering school while reading and writing are learned in school. Each of these skills is closely related to the thought processes that underlie language. A person's language reflects his thoughts. The more skilled a person is in language, the brighter and clearer his thinking is (Tarigan, 2015). Listening and reading are closely related because both are tools for receiving communication. Speaking and writing are closely related in that they are both ways of expressing meaning or meaning (Tarigan, 2015).

\section{RESEARCH METHOD}

The type of research used is quantitative research. According to Sugiyono (2013). The quantitative research method is a research method whose research data is numbered and analyzed using statistics. The research design that we will use is correlation research. According to Gay in Sukardi (2012), Correlation research involves collecting data to determine whether there is a relationship and the degree of association between two or more variables. If the correlation is significant in the study, what can conclude that the independent variable affects the dependent variable. 


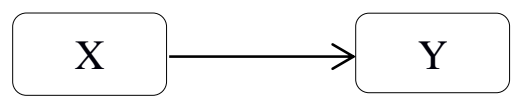

Information:

$\mathrm{X}$ : Student Reading Interest

Y: Student's Indonesian Learning Outcomes

The research will implement at SD Inpres 1 Donggulu, Kasimbar District, Parigi Moutong Regency. The sample in this study was class IV SD Inpres Donggulu, totaling 18 students. The instruments used for data collection are questionnaires and documentation. The measurement instrument used in this study is the Likert scale. Questionnaires are used to determine students' reading interests. Documentation of mid-semester exam scores to obtain data on student learning outcomes. Then the data were analyzed using descriptive statistics, normality test, product-moment correlation, and coefficient of determination (KD).

Descriptive analysis of reading interest and student learning outcomes using the following formula;

$$
\mathrm{Pk}=\frac{\text { Overall Score }}{\text { Total Maximum Score }} \times 100 \%
$$

The students' reading interest scores obtained from the formula were then converted to a qualitative assessment form by referring to the following criteria table.

Table 1. Criteria for Student Reading Interest

\begin{tabular}{cc}
\hline Score & Criteria \\
\hline $0-20$ & Very low \\
$21-40$ & Low \\
$41-60$ & Medium \\
$61-80$ & High \\
$81-100$ & Very high \\
\hline
\end{tabular}

(Source: Arikunto, 2013)

According to Arikunto (2013), the categorization of student learning outcomes is presented in the following table.

Table 2. Student Learning Outcomes Criteria

\begin{tabular}{cc}
\hline Number 100 & Information \\
\hline $80-100$ & Very well \\
$66-79$ & Good \\
$56-65$ & Enough \\
$40-55$ & Less \\
$30-39$ & Failed \\
\hline
\end{tabular}

Calculate the product-moment correlation with the help of the SPSS 24 application. Meanwhile, the calculation of the Coefficient of Determination uses the following formula.

$$
K D=r^{2} \times 100 \%
$$

Information:

$\mathrm{KD}=$ nilai koefisien determinasi

$\mathrm{R}(\mathrm{r})=$ nilai koefisien korelasi 


\section{RESULTS AND DISCUSSION}

In this study, the data presented includes student reading interest questionnaires obtained through questionnaires and grades of Indonesian learning outcomes for fourth-grade students of SD Inpres 1 Dongguan. Measurement of students' reading interest or variable (X) consists of four indicators: reading pleasure, awareness of the benefits of reading, reading frequency, and reading quantity. Student learning outcomes data or variable (Y) includes cognitive, affective, and psychomotor values. Student learning outcomes are taken from the documentation of students' Mid-Semester Examination scores in Indonesian subjects in the first semester of the 2019/2020 school year. The descriptive analysis of reading interest and student learning outcomes is presented in the following table. The tables are numbered in order. The title of the table is placed at the top with the position in the middle. Leave a space between the title and table. Use only horizontal lines to distinguish column headings from the table, and place them above and below. Enter the table in your writing and not enter it separately.

Table 3. Criteria for reading interest and student learning outcomes

\begin{tabular}{llccc}
\hline No & \multicolumn{1}{c}{$\begin{array}{c}\text { Criteria for Interest in } \\
\text { Reading }\end{array}$} & Percentage $(\%)$ & $\begin{array}{c}\text { Criteria for Learning } \\
\text { Outcomes }\end{array}$ & Percentage (\%) \\
\hline 1 & Very High & 27,78 & Very good & 61,11 \\
2 & Height & 55,56 & Good & 38,89 \\
3 & Medium & 16,66 & Enough & 0 \\
4 & Low & 0 & Less & 0 \\
5 & Very Low & 0 & Fail & 0 \\
& $\quad$ Total & $100 \%$ & & $100 \%$ \\
\hline
\end{tabular}

From table 3 above, it is known that students who have an interest in reading with very high criteria are $27.78 \%$. Interest in reading increases by $55.56 \%$, and the rest are in the medium standards. Directly proportional to the acquisition of student learning outcomes. The mid-semester test scores found that the students whose learning outcomes were excellent were $61.11 \%$. Learning outcomes with good criteria are $38.89 \%$. Based on this score, it is known that there is a relationship between reading interest and student learning outcomes.

The acquisition of students' interest in reading with very high and high criteria is caused by students' awareness of the importance of reading so that students like to read. Students also frequently visit the library - another effort to read to look for other reading sources. We can conclude that the reading interest of the fourth-grade students of SD Inpres 1 Donggulu is in the high category. The increased interest in reading students affects the achievement of learning outcomes.

The conclusion, hypothesis testing is carried out. Hypothesis testing in this study used Product Moment correlation analysis techniques with the help of the SPSS 24 application. The following is the result of product-moment correlation analysis of reading interest variables with student learning outcomes variables.

Table 4. Correlation Analysis of Reading Interest and Learning Outcomes

\begin{tabular}{cccc}
\hline & \multicolumn{2}{c}{ X } & Y \\
\hline Variable X & Pearson Correlation & 1 & $0,511^{*}$ \\
(Interest in Reading) & Sig. (2-tailed) & & 0,030 \\
N & 18 & 18 \\
Variable Y & Pearson Correlation & $0,511^{*}$ & 1 \\
(Learning Outcomes) & Sig. (2-tailed) & 0,030 & 18 \\
& & 18 & 18 \\
\hline
\end{tabular}


From the table above, we can be seen that there is a Pearson Correlation in the column where the $\mathrm{X}$ variable is one and the $\mathrm{Y}$ variable is 1 , which means that there is a perfect correlation. Based on the significant value of Sig. (2-tailed), if the value of Sig. (2-tailed) $<0.05$, then there is a correlation between the variables that are connected. On the other hand, if the value of Sig. (2-tailed) $>0.05$, there is no correlation. In the column, variable $\mathrm{X}$ is 0.030 , and variable $\mathrm{Y}$ is 0.030 , which means there is a correlation between variable $\mathrm{X}$ and variable $\mathrm{Y}$. Based on the asterisk (*) contained in Pearson Correlation, there is a correlation between the $\mathrm{X}$ variable and $\mathrm{Y}$ variable being analyzed.

The count value is compared with the r-table with a significance level of 5\%. If the count is greater than the r-table, Ha is accepted, and H0 is rejected, but if r-count is smaller than r-table, Ha is rejected, and $\mathrm{H} 0$ is accepted. Based on the table above, the Pearson Correlation or r-count is 0.511, which is positive, and the r-table is 0.468 , then the value of count is $0.511>r$-table 0.468 . it shows that $\mathrm{Ha}$ is accepted and $\mathrm{H} 0$ is rejected, which means a significant relationship between reading interest and Indonesian learning outcomes for fourth-grade students of SD Inpres 1 Dongguan. Based on the correlation coefficient interpretation table, the relationship between reading interest and Indonesian language learning outcomes for fourth-grade students of SD Inpres 1 Donggulu has a moderate level of relationship (0.511).

The coefficient of determination must be calculated to determine how much influence between variables $\mathrm{X}$ and $\mathrm{Y}$ is expressed in percentage form. Based on the coefficient of determination formula, the value of the coefficient of determination (KD) is $26 \%$. The interpreted that reading interest determines students' Indonesian learning outcomes by $26 \%$ and other factors that influence $74 \%$.

Based on the results of statistical calculations using Product Moment correlation analysis, it can be concluded that "There is a significant relationship between reading interest and learning outcomes of fourth-grade Indonesian students at SD Inpres 1 Donggulu". It is in line with Kuanaben's (2016) research, which concludes that reading interest has a positive and significant effect on writing essays in fifth-grade students, with the most considerable contribution of $9.9 \%$. The greater the student's interest in reading, the greater the ability to write articles. Therefore, interest in reading needs to be increased from an early age in children so that children can easily express ideas in writing or essays.

Interest is one of the internal factors that can affect student learning outcomes. According to Slameto in Hapnita et al. (2018) explained that "interest has a great influence because if the subject matter studied is not following interests, students will not study seriously." A person's interest can grow with a sense of love or pleasure and pay more attention to an activity or thing being done.

The learning outcomes indeed cannot be separated from the habits he does in his daily life to support his learning process. Positive activities will undoubtedly have a good impact on student learning outcomes. One of those good habits is reading. Farr in Dalman (2014) mentions that "Reading is the heart of education," which means reading is the heart of education. The more often someone reads, the more knowledge and insight will increase and become more comprehensive. The knowledge and understanding possessed by students will positively influence the success of the student's learning.

The relationship between reading interest and Indonesian language learning outcomes for fourth-grade students of SD Inpres 1 Donggulu has a moderate level of connection, namely 0.511 or $26 \%$ if present. At the same time, other factors influence the remaining 74\%. A student's reading interest will significantly affect student learning outcomes. One of the factors that influence the existence of a library is the strong interest in reading for fourth graders at SD Inpres 1 Donggulu. There are various kinds of reading books in the library, such as comics, storybooks, magazines, and other textbooks. 
Based on the study results, reading interest has a relationship with students' Indonesian learning outcomes. Interest is not brought from birth but must be cultivated. According to (Naim 2013), how to develop reading interest should be started early and intensively in the family and school environment. Then build a love for books. This love will make a person not feel bored or tired. The latter provides reading materials obtained from bookstores, libraries, exhibitions, thrift bookstores, the internet, and clippings. It is also based on opinion (Harjanto, 2011), which states that one way to foster interest in reading in children is: 1) getting children to read books; 2) take the child to a bookstore or library; 3 ) buy books that match the child's interests or hobbies; 4) exchange books with friends; 5) placing the book in an easily accessible place; 6 ) add to the collection of various kinds of reading books.

\section{CONCLUSION}

Based on the results of the research and discussion, the reading interest of the fourth-grade students of SD Inpres 1 Donggulu is in the strong category with a percentage of $83.34 \%$, and students' Indonesian learning outcomes are in the excellent category with a ratio of $61.11 \%$ and the suitable type. With a portion of $38.89 \%$. The results showed a significant relationship between reading interest and Indonesian language learning outcomes for fourth-grade SD Inpres 1 Donggulu students. The level of the relationship they have is in the medium category. So it can be concluded that there is a significant relationship between reading interest and learning outcomes of fourth-grade students of SD Inpres 1 Donggulu. The reading interest factor that contributes to the achievement of student learning outcomes is $26 \%$.

\section{REFERENCES}

Andriani, Rizal, \& Palimbong, A. (2014). Meningkatkan Hasil Belajar Siswa Pada Pembelajaran PKN Kelas V Melalui Metode Diskusi Di SDN No 1 Loli Londo. Elementary School of Education EJournal, Universitas Tadulako. 2(1), 51.

Arikunto. (2013). Prosedur Penelitian: Suatu Pendekatan Praktik. Jakarta: Rineka Cipta.

Azizah, \& Wanda Sari, A. (2020). The Application Model Learning Games ABC to Improve Result Of Learning. Jurnal Pendidikan Dan Pengajaran, Universitas Tadulako. 4(Nomor 5).

BSNP. (2006). Standar Isi untuk Satuan Pendidikan Dasar dan Menengah. BSNP.

Dalman. (2014). Keterampilan Membaca. Bandung: Rajawali Press.

Elfika, Tandi, H. Y., \& Firmansyah, A. (2014). Pengunaan Buku Paket Terhadap Prestasi Belajar Siswa Kelas IV SDN Inpres Tondo. Elementary School of Education E-Journal, Universitas Tadulako. 2(2), 63.

Hapnita, W., Abdullah, R., Gusmareta, Y., \& Rizal, F. (2018). Faktor Internal dan Eksternal Yang Dominan Mempengaruhi Hasil Belajar Menggambar Dengan Perangkat Lunak Siswa Kelas IX Teknik Gambar Bangunan SMKN 1 Padang Tahun 2016/2017. CIVED JURUSAN TEKNIK SIPIL, Universitas Negeri Padang. 5(1), 2176.

Harjanto, B. (2011). Merangsang dan Melejitka Minat Baca Anak Anda. Yogyakarta: Manika Books.

Kuanaben, Y. (2016). Hubungan Minat Membaca Dengan Kemampuan Menulis Karangan Siswa Kelas V SDN Jarakan. Jurnal Ilmu Pendidikan, Universitas Terbuka. 5(2), 62.

Naim, N. (2013). The Power Of Reading. Bandung: Aura Pustaka.

Reskia, S., Herlina, \& Zulnuraini. (2014). Pengaruh Tingkat Pendidikan Orang Tua Terhadap Prestasi Belajar Siswa Di SDN Inpres 1 Birobuli. Elementary School of Education E-Journal, Universitas Tadulako. 2(2), 84.

Slameto. (2013). Belajar dan Faktor-faktor Yang Mempengaruhinya. Jakarta: Rineka Cipta.

Sudarsono, B. (2010). Pembinaan Minat Baca. Universitas Terbuka.

Sugiyono. (2013). Metode Penelitian Pendidikan; Pendekatan Kuantitatif, Kualitatif, dan R\&D. Bandung: Alfabeta.

Sukardi. (2012). Metodologi Penelitian Pendidikan, Kompetensi dan Praktiknya. Jakarta: Bumi Aksara.

Tarigan, H. G. (2015). Membaca sebagai Suatu Keterampilan Berbahasa. Bandung: Angkasa. 